ISSN 2075-471X

www.mdpi.com/journal/laws/

Article

\title{
Privacy, Personhood, and Property in the Age of Genomics
}

\section{Wendy Bonython * and Bruce Baer Arnold}

School of Law, Faculty of Business Government and Law, University of Canberra, Canberra 2601, Australia; E-Mail: Bruce.Arnold@canberra.edu.au

* Author to whom correspondence should be addressed; E-Mail: Wendy.Bonython@canberra.edu.au; Tel.: +61-2-6201-5770.

Academic Editor: Aurora Plomer

Received: 7 May 2015 / Accepted: 24 July 2015 / Published: 30 July 2015

\begin{abstract}
Revolutions in genetic technology have heralded the age of population-scale genomic metadata. This article analyzes the tensions and gaps between traditional conceptions of personhood and international legal responses to a person's right over disembodied data obtained from his/her body. The opportunities for breakthroughs in healthcare by interrogating population-scale genomic databases are accompanied by questions about privacy, property, dignity, and the nature of information regulation in a global economy. This article highlights instances where law and policy makers have grappled with these challenges, and foreshadows some emerging future challenges. It also highlights differences between jurisdictions, and calls for greater global participation in the development of a coherent framework, rather than continued reliance on a small number of stakeholders, to develop that framework.
\end{abstract}

Keywords: genomic; privacy; bioethics; law

\section{Introduction}

Deoxyribonucleic acid—DNA — is inherently paradoxical. Unique sequences within an individual's DNA can confirm or refute that person's alleged presence at a crime scene with an extraordinary degree of specificity $[1,2]$. Conversely, commonality between the genetic sequences of individuals can be used to establish their relationship to others, including via far distant ancestors, to the utility of genealogists, anthropologists, and archaeologists alike [3-5]. Increasing use of DNA as a tool for the 
identification and interpretation of individuals and cohorts poses challenges for how societies and legal systems construe personhood, the foundation for the rights enjoyed by human animals under national and international law [6-10]. It provokes questions about tensions between personal and social goods, tensions evident in all privacy and intellectual property law. It also provokes questions about abstraction. Do we regard people merely as manifestations of genetic data that are appropriately mined and propertized, or as entities that are outside the realm of commercial use, an exclusion symbolized by longstanding Anglo-Saxon jurisprudence about "no property in the body" [11-15]? That exclusion is increasingly contentious as courts grapple with disputes about gene patenting, the commoditization of cell lines for research and therapy, whole-population health "big data" initiatives such as the United Kingdom's care.data program, and excitement about personalized medicine [16-19].

Over several centuries the law in Australia, the United Kingdom, Canada, New Zealand, and other countries has regarded people as flesh and blood creatures whose vulnerability requires a legal framework that fosters individual and collective welfare [20,21], and who are distinct from other animals. The advent of genomic technologies - unlocking what has variously been dubbed the "book of life" and the "blueprint of life" - has encouraged an awareness that we share many characteristics with other organisms and that racial differentiation is biologically rather than merely ethically indefensible [22]. More subtly, those technologies potentially encourage the erosion of traditional views of personhood, with people being viewed as expressions of genomic data - a compendium of "selfish genes" that can be mapped [23], manipulated [24-26], marketed [27], or used for risk allocation [28-30]. Ethicists and jurists look askance at the sale of people, for example, through reference to prohibitions on slavery and criminalization of people trafficking [31]. In contrast, they are likely to be receptive to the establishment of exclusive rights regarding information and a vigorous global trade in information, for example, because there is a longstanding legal discourse about intellectual property [32], reflected in global frameworks such as the agreement on Trade-Related Aspects of Intellectual Property (TRIPS) [33]. What, then, are the consequences of regarding people as data rather than as persons?

This article engages with those consequences by exploring a set of discrete issues regarding law around the market for diagnostic biotechnology (for example, property rights in cell lines and gene patents), around privacy (for example, dilemmas regarding direct-to-consumer (DTC) genetic testing and sale by governments of population-scale health records), and around highly customized "precision medicine" [34,35]. It has been written for non-specialists interested in perspectives that transcend particular jurisdictions (such as jurisprudence in the United States regarding commercialization of cell lines) and that offer cautions regarding technologies such as deidentification that are unlikely to offset potential harms associated with whole-population genomic profiling.

Section 2 of this article introduces the notion of the "informational body" as a starting point for identification of questions regarding dignity, consent, genomic privacy, the commercialization of genetic data and cell lines, and genome-based therapies that are specific to individuals.

Section 3 places the "genomic revolution" in context, highlighting some of the claims about the tools for and consequences of reading (and even editing) what has popularly become known as the "book of life". It discusses the emergence of commercialized direct-to-consumer genetic testing, and the ethical and legal implications associated with tardy regulation of that sector, but also the direction of public funding into "precision medicine" initiatives occurring in several key jurisdictions, without adequate policy or legal consideration for the rights of consumers or donors. 
Section 4 examines the emerging jurisprudence on property rights over diagnostic biotechnology, including the cell line and biorepository cases of Moore v. Regents of the University of California, Greenberg v. Miami Children's Hospital, Washington University v. Catalona, and Havasupai Tribe v. Arizona State University Board of Regents, and the recent litigation in Australia and the United States over the Myriad Genetics BRCA1 patents.

Section 5 considers the provisions addressing donors and consumer rights and protections available under international law, and their limitations.

Section 6 offers conclusions, suggesting that some otherwise intractable challenges may be addressed through an ethic of custodianship rather than ownership, reflected in for example a genomic commons and in a stronger emphasis on informed consent regarding the long-term uses of genomic data and materials.

\section{Personhood, Privacy, and Propertization}

Personhood is a protean concept, evident in philosophical and legal literature [36-38]. It is the foundation of the law and bioethics of the contemporary liberal democratic states [39,40]. It should be borne in mind in considering questions about consent, responsibility, social good, and self-ownership. Those questions are pertinent in a new environment where there are potential major benefits for individuals and societies in the application of genomic technologies (for example, identification of associations between diseases and genetic attributes as the basis for diagnoses and therapies) and where there are potential harms from regarding individuals as sources of research/therapeutic material or as manifestations of genomic data rather than people.

\subsection{Conceptualizing Personhood}

Legal practitioners, public policy makers, and people without legal or medical expertise alike typically conceptualize the human animal in terms of a personhood that has facets such as gender, age, mental/physical disability, sexual affinity, education, and ethnicity. That conceptualization often valorizes relationships such as citizenship, employment, and marital status. It may feature identifiers such as names, social security or tax file numbers, passports, and fingerprints. It may be construed as a matter of legally enforceable rights and duties or capabilities, some of which may be apparent in the conceptualization of artificial persons such as corporations [41,42] and in questions by figures such as Wise and Singer about whether nonhuman animals (such as chimpanzees) should be recognized in law and bioethics as having some or all of the attributes of personhood [43-45].

It is axiomatic, however, that people are more than specific attributes or relationships. The imperatives of medical research, diagnosis, and treatment may foster a disrespect of personhood by emphasizing public goods at the expense of personal dignity, with, for example, a perception that it is appropriate for researchers to exclude an individual from financial rewards attributable to commercialization of that person's excised tissue, given that profit-oriented investment fosters scientific advances as the basis for innovative diagnoses/therapies benefitting the community as a whole [46]. Such a perception is consistent with longstanding doctrine, highlighted in Section 3 of this article, that the individual has no "property in the body" or, by extension, in excised body parts. Less clear, however, is why the alienation of all rights, including "lesser" or non-commercial rights such as 
the right to withdraw consent, or the right to remain informed, must necessarily continue to be linked to donor financial rights, as recognition of the value to some donors of those non-commercial rights increases. More subtly, imperatives may lead regulators, researchers, and clinicians to view individuals as sets of attributes - for example, as a genomic profile - rather than as a person. In the coming age of population-scale biobanks and genomic profiles, we should recognize the benefits of new technologies while seeking to avoid harms attributable to disrespect of personhood. James Scott famously highlighted the dangers inherent in "seeing like a state", i.e., utopian social engineering projects that disregard individual rights and override personal autonomy in the name of a greater good [47]. In recalling Kant's exhortation not to conceptualize people as a means to an end, irrespective of the claimed beneficence of that end, we should be wary about "seeing" like a genetic profiler or patent applicant [48].

\subsection{Research, Personhood, or Both?}

Such wariness is not antithetical to research or to the public goods that are outcomes of patent law in Australia, the United States, and elsewhere. It is consistent with frameworks such as the Belmont Report and Helsinki Declarations, the statement by the U.S. President's Commission for the Study of Bioethical Issues, publications by the Nuffield Council on Bioethics, the Bermuda Principles, and the research guidelines issued by regulators, such as the National Statement on the Ethical Conduct of Human Research issued by Australia's National Health \& Medical Research Council [49-54]. It does require consideration of mechanisms for full disclosure of how genetic material/data is used and of questions around a genomic commons to address problems such as the Myriad patent problem discussed below. It also requires a more nuanced appreciation on the part of researchers and database operators of concerns regarding privacy, trust, and consent.

The following pages indicate that such an appreciation does not represent a serious barrier to the advancement of medical science or a fundamental deterrent to investment by life science enterprises, insurers, and other entities whose decision making is determined by the financial bottom line. It is consistent with bioethics principles and with privacy law. Legal recognition of privacy-succinctly characterized as freedom from inappropriate interference - has never been absolute; rather, it has been founded on proportionality, balancing respect for human dignity, which recognizes the individuals' autonomy to determine when they might waive that right, against the interests of the community or state [55-57].

\subsection{A Right to Privacy?}

In making sense of privacy it is pertinent to recall that privacy as a human right is recognized in both the Universal Declaration of Human Rights [58] and subsequent conventions [59,60]. It coexists with professional codes and the body of law regarding patient-clinician confidentiality [61]. It is specifically enshrined in a range of information privacy statutes in different jurisdictions [62-65] and in case law regarding misuse or inappropriate access to sensitive health information [66]. It is also a focus of Organisation for Economic Cooperation \& Development (OECD) proposals for global health data guidelines that will inform further development of national data protection statutes and practitioner codes [67] and of work by the Article 29 Working Party regarding autonomy and informed consent under the European Union data and consumer protection regime [68]. In advising on the 
development of European law, which has a global impact both as a benchmark [69,70] and because many non-European enterprises want access to the European market [71,72], that Working Party has emphasized the importance of consumer understanding as a prerequisite for consumers commodifying their data. This article returns in Section 5 to challenges of informed consent in dealings with genomic data and materials in global markets.

\section{Reading and Rectifying the Book of Life}

It is axiomatic that DNA - particularly if correctly interpreted and associated with other data about, for example, an individual's lifestyle or exposure to harms such as toxic substances-provides researchers and clinicians with potentially invaluable information about disease and human health. Unlocking that information has proven difficult; many medical conditions are not attributable to a single gene, but instead result from complex interactions between multiple genes and environmental factors [73]. Enthusiasm in the mass media regarding a single genomic 'silver bullet' for diagnosis and cure of some diseases - notably cancer — is technically uninformed and ethically problematical $[74,75]$.

\subsection{Propertizing Pathology through Patents}

Disease - its detection and treatment - is big business: the global in vitro diagnostics market is predicted to be worth nearly US\$55 billion by 2018 [76]. Unsurprisingly, commercial entities competing in this market are vigorous in defending their commercial interests in the diagnostic technologies and tools they develop, and also the resources they require to develop and validate those tools and technologies [77]. Those commercial interests lie at the heart of litigation arising in the United States and elsewhere in recent years, for example the Myriad patent disputes in Australia and the USA that are discussed below. However, those interests may not coincide with the interests of those who donate their biological material, or those who will ultimately become consumers [78-80].

In the absence of a coherent global legal and regulatory framework, litigation of this type, combined with enactment of domestic legislation, will force evolution of an ad hoc system of genetic and health privacy governance susceptible to both regulatory arbitrage and political pressure from commercial interests, neither of which is likely to result in robust protections, or equitable outcomes, for consumers or donors. In 2000, it was announced that the first "working draft" of the human genome had been completed [81-83]. Two groups, one a multinational public cooperative, the other-Celera - a private U.S. biotech company, had been locked in a modern equivalent of the space race, where the challenge was to sequence the entire human genome, some 3 billion base pairs of DNA representing some 20,000 genes, arranged into 23 chromosomal pairs, a complete copy of which is present in the nucleus of the majority of cells in the body [84].

Significantly, the original "working draft" was not the entire sequence of one individual's genome; rather, the draft produced by each of the competing organizations was a composite, made up of fragments of the genome of multiple consenting participants of varying ethnicity. The publicly funded genome reportedly cost $\$ 3$ billion; Celera's version reportedly cost $\$ 300,000,000$ [85].

In the intervening 15 years since completion of the working draft was announced, the costs of genomic sequencing have fallen significantly [86]. Furthermore, other high-throughput genetic analysis technologies capable of analyzing many sites in the genome, without necessarily requiring 
sequencing of the entire genome, have been developed. Genome-wide association studies (GWAS) typically assess differences in the frequency of sequence variants located in specific regions throughout the genome between people with different characteristics or attributes, e.g., a control group whose members are free from a particular disease, and a test group whose members have that disease. If variations occur at higher frequencies in one or the other group, that variation becomes a candidate genetic cause of the conditions, worthy of further testing [87].

GWAS represents a major advance in our understanding of the genome. However, it has not been free of controversy. Critics of GWAS have identified a number of problems with the methodology, including that typically genetic variants identified in this way only account for comparatively small increases in disease risk [86], and that the results are susceptible to population stratification, i.e., the predictive value of a particular association may be dependent on the age, gender, or ethnicity of the population in which it was originally identified [88]. Furthermore, GWAS only results in identification of candidate genetic variants: verification of the variant as a true risk factor, rather than an experimental artifact, typically relies on more targeted experimentation, such as linkage or functional analysis [89].

\subsection{Mining the Genome}

Notwithstanding these limitations, a number of commercial entities have embraced GWAS technology, in both direct-to-consumer and traditional practitioner-mediated models [89-91]. That embrace has been accompanied by disagreements regarding informed consent, a matter highlighted in Section 2 of this article, and about ownership of the genomic information [92-94]. It has also sparked disagreement about notions of "genomic sovereignty" [95] and postcolonial "biocapital" [96,97], notions that have more academic traction than acceptance in court. One example of large-scale commercial genomics identification, with consequent questions about informed consent and ownership, is deCODE.

In 1998, the parliament of Iceland passed laws permitting a privately owned company, deCODE, to construct a national database containing the health records and genetic and genealogical data of the country's entire population-some 270,000 citizens. The legislation also granted deCODE exclusive commercial rights over the database for a period of 12 years $[98,99]$.

A number of characteristics of the Icelandic population make it an attractive target for population-based genetic studies, including limited migration for a long period, good living standards, and comprehensive medical and genealogical records for the entire population, frequently accompanied by tissue samples [100]. Relying on a restricted consent model, which required Icelanders to opt out of inclusion, the project was subsequently found to breach Iceland's privacy laws [101] and amid financial difficulties the compilation of the database ended [102,103]. The company subsequently switched to using the Internet to market personal genome scans-testing for over one million single nucleotide polymorphisms - directly to consumers anywhere in the world.

In doing so, deCODE joined the emerging population of direct-to-consumer genetic testing service providers. Derived from other direct-to-consumer marketing models established in sectors including pharmaceuticals, consumers could source services without requiring a clinician or health provider to act as an intermediary.

The phenomenon of direct-to-consumer genetic testing began to emerge in the early 2000s, shortly before the final version of the human genome was published in 2004 [104]. 
In 2002, Sciona began offering tests for a small number of genetic polymorphisms directly to customers (i.e., without referral by a medical practitioner) in the United Kingdom through the Body Shop, a cosmetics retailer. In exchange for providing a sample of their DNA, customers were provided with "genetically informed" advice on changes they could make to their diets to enhance their wellbeing $[105,106]$.

DTC is a model of genetic testing where consumers (rather than patients, participants, or donors) engage directly with the genetic testing provider, eliminating healthcare professionals as intermediaries. By marketing directly to consumers, the DTC industry sought to distinguish its services from the regulated diagnostic tests used by clinicians. This model also cast users of DTC services as consumers who pay for a service, like any other commercial transaction, rather than patients whose testing is requested by a healthcare professional acting on their behalf $[107,108]$. This has facilitated marketing strategies that appeal to potential customers' sense of autonomy and empowerment, creating a vocal body of supporters who oppose DTC regulation on the basis that it is interference by the state with the individual's right to access their own genetic information [109-111].

The partnership between Google and the newly formed 23andMe visibly formalized the relationship between big data informatics and genomics [112]. Amid much fanfare-including some highly publicized celebrity "spit parties" [113,114]—23andMe's offerings have included tests pitched towards those with an interest in their ancestry, recreational "fun" genetics, and-more problematicallyhealth and disease risk.

\subsection{Regulation: for Whom, by Whom, How, What, and Where?}

Over time, the costs of the services offered fell dramatically, and the number of companies offering services directly to consumers fluctuated. The nascent industry attracted extensive criticism, much of which was directed at the issues identified with GWAS earlier, principally that the results lacked both utility and validity [115-122]. Concerns about consumers relying on the results of DTC genetic tests to make potentially significant lifestyle choices were widely expressed. In the U.S., for example, the Government Accountability Office reported concerns about DTC genetic testing shortly after it emerged onto the market. Eventually, regulators began to view the disease prediction related services as a target for regulatory intervention, culminating in some European jurisdictions prohibiting DTC, while the FDA issued providers of DTC testing services to consumers within the United States with orders to cease offering the services, pending FDA approval for their use [123-126].

Companies offering the services sought to get around FDA regulations - limited by statute to health tests-by stating that the tests were not diagnostic, notwithstanding that in many instances they were marketed to consumers on that basis. Significantly, the FDA lacks the power to regulate tests using identical technology that are ancestral or recreational rather than health related. It is, therefore, possible, that in the event of a challenge to FDA regulation of DTC, the courts may find that the FDA does not have the power to regulate the tests. Problematically, although the DNA samples may be provided by people seeking genetic information about their ancestry or other concerns, the wording of agreements between data subjects and service providers means that there is little preventing those providers from subsequently using that stored DNA sequence data and related personal information in health-related research. Some providers served with FDA letters have subsequently sought FDA 
approval for specific tests within their arrays; however, as each test in the platform used must be approved individually, full registration is likely to take a long time, and incur considerable cost.

Further complications arise in considering that multiple agencies are potentially involved in regulating different aspects of the same service. While drug and medical device agencies such as the U.S. Food \& Drug Administration or Australia's Therapeutic Goods Administration may have carriage of regulatory concerns regarding the utility and validity of the tests themselves, other agencies - such as the U.S. Federal Trade Commission, or the Australian Competition and Consumer Commission or Office of the Australian Information Commissioner - may be responsible for privacy and for regulation of advertising or imports, including statutes and co-regulatory codes regarding direct-to-consumer marketing across borders of what might otherwise be regarded as health services.

In focusing on the consumer protection issues, however, policymakers have overlooked the stated primary objective of DTC providers, which is to collate large-scale databases of health and genetic information provided by consumers, for subsequent commercial use - a purpose that has not always been evident from the information provided to consumers in obtaining their consent $[127,128]$. From this perspective, consumers of direct-to-consumer genetic testing services are more appropriately viewed as donors or research participants, albeit donors who may pay for the privilege of contributing to a commercial biobank.

\subsection{Consumers, Research Subjects, or Participatory Citizens?}

Announcements of public support for "personalized" or "precision" medicine initiatives - construction of large-scale genetic and/or health information databases - by a number of governments in recent times have provided genomic research with much-needed credibility. The lack of participant payment underpinning these projects highlights the need for regulators to view participant protection more broadly than as a consumer protection issue alone. Unfortunately, these projects-including the United Kingdom's 100,000 genomes project, the Australian National Health \& Medical Research Council's "Preparing for the 'omics' Revolution in healthcare" strategy, and the U.S.'s "Precision Medicine Initiative"-embody a utilitarian rather than dignitarian ethic [129-131]. They have not been accompanied by coherent legal and policy reform. Consequently, these publicly funded research programs will present the same ethical and legal questions-regarding consent, ownership, and control of donated genetic and health information - as their commercial direct-to-consumer counterparts.

The cross-generational nature of genomic data means that both the overtly for profit and the not-for-profit genomics projects involve challenges that should be addressed up front, rather than on a retrospective basis $[132,133]$. Who, for example, will own the data? Who will control its commercial or non-commercial use, particularly in environments where the differentiation between commercial and noncommercial in public/private sector partnerships is unclear and where governments are seeking to offset their financial weakness by providing life sciences enterprises with privileged access to public data? And, equally importantly, who will benefit from it? 


\section{From Worm Bites to Mega Bytes?}

"The burial of the cadaver, that is caro data vermibus (flesh given to worms) is nullius in bonis and belongs to ecclesiastical cognizance; but as to the monument, action is given, as has been said, at the common law for the defacing thereof."

—Lord Coke (3 Coke's Inst. 202)

Historically, Western tradition conceptualized the body as little more than a vessel for the spirit or soul contained within it, rather than as a manifestation of genomic data that could be mapped on a population scale and analyzed as the basis of diagnoses and therapies. Corporeal remains (i.e., the cadaver or body parts) had no purpose surviving the death of a person apart from burial —itself a practice grounded in pragmatism and public hygiene as much as religion. The law recognized no legal claim to the body, save the limited claims of those involved in finalizing the deceased's affairs to ensure that a "proper Christian burial" occurred, cremation at the time being contrary to the rule of the church.

The scandal of the so-called "resurrectionist men" in Britain in the 1700s - men who would exhume recently buried corpses and sell them to teaching hospitals for dissection-demonstrated clearly that human corpses had acquired a commercial value and purpose, albeit it limited to the black market [134]. Advances in blood transfusion, organ transplantation, assisted reproduction, cell culture, and a range of other medical technologies now mean that bodies and parts of bodies - tissues, organs, and cells - can serve functions separate from, and surviving the death of, the donor. Gene sequencing technology now enables the genetic content of a person to be isolated from their cells, and transformed into pure data, potentially endlessly replicable and existing in perpetuity.

The conception of the body has therefore evolved from the purely tangible, intact, and finite, to encompass the immortal, fragmentable, and intangible.

Legal responses to these changing conceptions and technological advances have largely been reactive and incoherent. Rather than developing a new legal paradigm, existing precedent has instead been tortuously applied to accommodate fact scenarios beyond the wildest dreams of Coke and his contemporaries, often with some profoundly unsatisfactory consequences. Examples of tortuous tests include findings that special transformative skills have been applied to the material in question [135], or that something novel and not obvious had been done [136], even when an independent assessment of the facts challenges the "specialness" or "novelty" of those steps [137,138].

To add to the incoherence, legislatures have often responded to societal and bioethical concerns about the implications of emerging technologies by passing poorly conceived legislation, which frequently serves to confuse, rather than clarify, the status quo [139].

\subsection{Donors, Owners, or Refuse?}

Some of the earliest examples of the tensions between the competing interests of donors and others in this context relate to Western law's conception of property, and the apparent differential treatment it affords to bodies [140].

In legal parlance, property refers to the rights associated with a thing, rather than the thing itself. More than one person can have property rights in a thing at a given point in time: I may own a house; 
my tenant may be in possession of it; and my bank may hold a mortgage over it, for example. My neighbor's child may have license to enter the garden to retrieve a ball; a door-to-door salesman or utility worker might have a different type of license to enter and ring the doorbell, or read the meter. My tenant's friend might be invited over to share a meal. All of these people have certain rights with respect to the same house, potentially concurrently. While some of those rights may overlap, in no two of the parties mentioned above are they a perfect match.

In his landmark model of property based on common law, Honore conceptualized property as a collection of incidents of property — often likened to a bundle of sticks — with each 'stick' representing different rights with respect to the subject matter [141]. Property, as per this model, is inherently flexible and capable of customization to address the competing interests and requirements of multiple parties. Furthermore, equity has a long history of intervening to relax the formal rules of property to avoid unjust hardship on a dispossessed party [142]. That relief of hardship is, for example, evident in recognition of equitable mortgages and rights over property.

The flexibility noted by Honore also applies to intellectual property law, the body of law dealing with intangible, rather than real, property. Governed by legislation in many jurisdictions, intellectual property law nonetheless recognizes a variety of arrangements to apply to the use of intellectual property, including — but not limited to — commercial licenses for exclusive use [143].

Notwithstanding the flexibility permitted under law, the courts have curiously adopted an absolutist position, typically recognizing rights being vested in one private party at the expense of all claims brought by any other, excluding limitations imposed by laws - for example, jurisdictional limitations, or illegal or immoral purposes.

Both bioethics and law heavily employ donor discourse, where donation of tissue or material is described as a 'gift' - a legal status that, by definition, means an unconditional alienation of all rights of the donor with respect to that subject matter [144]. While much of the purported justification for non-recognition of donor rights is grounded in concerns about the impact of commodification on human dignity, this approach ignores the non-commercial nature of some of the rights donors are currently forced to relinquish, including rights such as privacy and full—and ongoing — disclosure.

\subsection{Donor Rights under the Microscope}

Public awareness of, and momentum for reform of, issues over donor rights, consent, and research ethics typically resurfaces amid revelations of historical events: the Nuremberg doctors trials resulted in the Nuremberg Declaration, subsequently leading to the Declaration of Helsinki; the Tuskegee Syphilis study - a notorious clinical study examining the progression of untreated syphilis spanning a period from the 1930s until the 1970s — prompted the Belmont Report in the U.S., leading ultimately to the introduction of formal ethics review processes for medical research. More recently, the publication of Rebecca Skloot's 2010 book The Immortal Life of Henrietta Lacks [145] brought the significance of informed consent and donor rights over biological materials to the forefront of the consciousness of the public.

In the book, Skloot detailed the origins of one of the most ubiquitous cell lines used in medical and biotechnological research, known as the HeLa cell line. Isolated in 1951 from the aggressive cervical cancer biopsy of a young black woman called Henrietta Lacks, the cells were transformed into a cell 
line without her consent or knowledge. That cell line was subsequently commercialized, again without the knowledge or consent of her survivors, who received no acknowledgement of her contribution, financial or otherwise. Contrary to the beliefs of some commentators, that commercialization did not take place within a bioethics or legal vacuum. Granted, the prevailing ethical and legal standards of the period may have been different from today's, but they nonetheless existed.

Authors commenting on both Lacks and Tuskegee have traditionally attracted criticism for hindsight bias - judging the practices of physicians and researchers operating in an earlier, more paternalistic era of medicine against a modern-day framework of research ethics regulation. Such criticisms are misguided on at least two counts.

Firstly, those criticisms assume researchers should only be directed by those ethical considerations that have been identified to them through a formal legal framework, and that their personal understanding of ethics has no role to play in governing their professional activities, a position that mischaracterizes those frameworks; typically, they identify minimum standards. Researchers whose personal ethics directs them to exceed those frameworks are not prevented from doing so, and indeed may be encouraged insomuch as they are promoting best practice, rather than minimal compliance. This is particularly important when researchers are engaged in novel work that is outside the scope of the existing ethical framework: researchers have a role to play in developing the standards that will ultimately govern the ethics of other researchers seeking to employ that new technology.

Secondly, and perhaps more importantly, it suggests that reflection on situations where ethics have fallen short of current requirements is of necessity punitive towards those conducting the research. While this may be true to an extent, it disregards the value of "lessons learned" analysis, which can usefully inform debate and direct reform towards preventing similar situations in future.

Further compounding the harms done to Henrietta Lacks and her family, in 2013, the journal G3: Genes/Genomes/Genetics published online an advance version of an article reporting the genomic sequencing by a team of researchers from the European Molecular Biology Laboratory (EMBL) of the HeLa cell line, discussed earlier [146]. Concurrently, the journal Nature was preparing to publish its own more detailed genomic sequence of the cell line, this time carried out by American researchers funded by the U.S. National Institutes of Health [147]. Somewhat surprisingly, the EMBL team did not consult with Lacks' family prior to submitting the article and making the genomic sequence freely available via the Internet. Press releases by EMBL at the time of the article's release claimed that we "cannot infer anything about Henrietta Lacks' genome, or of her descendants, from the data generated in this study" - a claim that was disproven when some researchers who had downloaded the genomic sequence ran it through a publicly accessible gene analysis database, yielding large quantities of personal genetic information about Lacks and her descendants. The researchers did not publicly release the results of that analysis; they did, however, share them with Rebecca Skloot, who wrote an op-ed piece in the New York Times [148] responding to the article. After being contacted by the Lacks family, EBML took the sequence offline and retracted their claim. By that time, however, the genomic sequence had already been downloaded a number of times.

After negotiations involving the NIH, EMBL, and members of Lacks' family, a compromise was reached: access to the sequences would be provided to researchers on an application basis, limited to use in biomedical research. Applications for access would be subject to the approval of a committee, 
which included members of the Lacks family, and appropriate acknowledgment of Lacks in any resulting publications would be a condition of access to the sequence data [149].

The agreement, while appropriate in the case of HeLa, hardly provides a sustainable model for management of genomic privacy or respect for human dignity. It is, rather, a reactive response to a fundamental and systemic failure to consider the ethical issues associated with research of this type, appropriate under circumstances such as this where the tissue in question was isolated decades earlier, in a time with substantially different ethical and legal standards. A far better approach would be to ensure that adequate safeguards exist under law and bioethics to prevent similar cases from ever occurring again, potentially including mechanisms for researchers to contact donors or their survivors and seek consent prior to using archived or stored material for applications not possible at the time the tissue was collected.

The case provides a salutary lesson for researchers doing genetic research on tissue that was isolated or archived a long time previously, including highlighting some of the issues arising when donor consent for use substantially predates technological development.

Characteristic of both the Tuskegee study, and the creation of the HeLa cell line is the fact that they occurred in an era influenced by law that centered on living humans in their entirety, rather than their disembodied tissues and the data they contain, expressions of what this article has earlier characterized as the informational body [150].

More recently, Moore v. Regents of the University of California [151], Greenberg v. Miami Children's Hospital [152], and Washington University v. Catalona [153] all addressed disputes arising from the use of tissue removed for the primary purpose of treatment, and subsequently repurposed for research, or donated for research purposes, which subsequently became commercial.

In Havasupai Tribe v. Arizona State University Board of Regents [154], the donors consented to donating blood for a specific research activity, but were not advised when their donations were subsequently used for different research purposes. In each case, the quality and scope of the consent provided by the donor was a significant, but not legally determinative, issue [155], differing from Lacks, where consent was entirely absent.

In Moore v. Regents of University of California, the plaintiff's spleen was removed, ostensibly for therapeutic purposes as part of his treatment for hairy cell leukemia. The treating physician, in conjunction with others, developed a cell line from lymphocytes isolated from Moore's spleen, which they and the University of California subsequently patented and commercialized. Moore sought to recover a portion of the proceeds from commercialization. The Supreme Court of California found that the physician's failure to disclose the commercial aspects of his plans was a breach of fiduciary duty, which may have compromised the quality of the consent provided by Moore but did not alter the fact that Moore did not retain any ownership rights in the tissue once it was removed from his body. The cells that constituted the cell line were a modified version of those originally isolated, which Moore had never had ownership or rights over; consequently, he was not entitled to any share of the proceeds [156].

In Greenberg v. Miami Children's Hospital, the plaintiffs donated biological tissue and other information to a researcher for the express purpose of developing prenatal and carrier screening tests for Canavan Disease, a rare and lethal genetic disorder particularly affecting Ashkenazi Jewish populations. The plaintiff's intention was to make the testing freely available to at-risk people; the 
defendant researcher and his employer began enforcing their claimed intellectual property rights, charging royalties each time the test was performed, at which point the plaintiffs discovered the defendant's commercialization intentions for the test. Once again, the court found that plaintiffs had no interest in the transformed or derivative product of their original biopsied material. Furthermore, despite recognizing an ethical obligation to obtain informed consent from donors, the court refused to extend the required information to include commercial interests; it did note that the American Medical Associations Code of Medical Ethics required disclosure of commercial interests, but disregarded this requirement on the basis that the code postdated the commencement of the research.

Washington University v. Catalona addressed the issue of control over biological samples after donation to a tissue bank. In that case, a surgeon and researcher (Catalona) collected tissue samples removed during surgical procedures for prostate cancer, for subsequent inclusion in a tissue bank. Donors signed consent forms, and were aware that their donated tissue and blood samples would be used for research purposes. Typically, the language of the consent forms permitted the donors to withdraw from the study at any time; they did not (and indeed could not, under legislation governing the disposal of medical waste) grant the donors any rights to return of the material subsequent to donation; an accompanying brochure did provide donors with the right to request destruction of their donated tissue samples, in the event they withdrew from the study.

Catalona subsequently accepted a position at another university, and distributed letters to donors seeking their approval to release the samples to him, for transfer to his new institution. Washington University sought a declaratory judgement identifying the university as the owner of the samples, while Catalona sought a declaration recognizing that donors had the right to approve transfer of the samples to him [157].

The District Court for the Eastern District of Missouri found that the University owned the samples, and that donor authorization of transfer of the samples to Catalona's new institution was consequently invalid, a position subsequently upheld by the United States Court of Appeals for the Eighth Circuit [158]. Significant in both decisions was the status of the materials as "gifts"; the Court of Appeal judgement, in particular, examined the consent forms and information brochures, and concluded that while inter vivos gifts could, at law, have conditions attached to them, the contents of those documents made it clear that retaining control over the transfer of those donated samples was not one of the conditions of the donation in this instance.

The importance of, and limitations of, consent in tissue banking again emerged as a topical issue in Havasupai Tribe v. Arizona State University Board of Regents. Featuring prominently in this case was the significance of cultural and spiritual identification of participants belonging to particular populations, in addition to the individual harms potentially arising from inadequate consent and protection of donor rights. In 1990, Arizona State University oversaw a project involving the collection of blood samples from members of the Havasupai tribe, for what donors believed would solely be research into the prevalence of diabetes. Subsequently, the blood was shared with other researchers, and used for other research, including into schizophrenia, without the appropriate consent of donors.

Seven years after members of the tribe initiated litigation against the university, the parties settled the dispute [159]. Terms of the settlement included paying the tribe $\$ 700,000$ (in recognition of the "dignitary, cultural, and other harms" suffered by the tribe, rather than the commercial value of the tissue collection); return of all remaining blood samples, and documents containing research based on 
those samples; termination or refusal of ethics approval for any additional research; details of all others who received samples from the study; and a range of partnership initiatives between the tribe and the university designed to address areas of need [160].

Settlements of this type do not provide a binding legal precedent. However, Havasupai does suggest that the reputational harm experienced by the university was sufficient to persuade them to resolve the dispute, notwithstanding that there was a strong legal—if not ethical—precedent to support their claim based on the earlier decisions. The valuable insights into the genetic basis of certain diseases provided by community-based research activities of this type must be balanced against the needs and rights of the community in question. Often, the very characteristic that makes a particular community attractive for research purposes, such as high incidence of a particular disease of trait, accompanies other characteristics that make that community vulnerable, such as socioeconomic or other disadvantage. To date, when grappling with personhood the law has not formally demonstrated recognition of group harms - including to the privacy of a group - in addition to harms potentially occurring to individual members of that group [161-164].

\subsection{Protecting Your Genomic Investment}

In addition to asserting claims over tissue samples and products derived from them, the courts have overseen a number of disputes about the patentability of modified genes, and even whole animals arising from genetic modification.

Recently, Myriad Genetics Inc. has experienced challenges to its patents of the BRCA1 sequence, associated with certain classes of breast cancer. In Association for Molecular Pathology v. Myriad Genetics [165], the U.S. Supreme Court found that merely isolating a naturally occurring DNA sequence did not make it patentable; however, converting it into cDNA (a step requiring manipulation) would result in a patentable sequence. The Australian Federal Court, in Cancer Voices Australia v. Myriad Genetics Inc. [166], differed, finding that isolation and purification of a naturally occurring DNA sequence was sufficiently removed from naturally occurring DNA to warrant patent protection, a position which survived appeal to the Full Court of the Federal Court [167].

The Australian Myriad dispute is currently being appealed to the High Court [168]. The consequences of that decision will possibly be short-lived. Australia is currently in negotiations with the United States and other nations to finalize the Trans Pacific Partnership Agreement (TPPA), the multilateral free trade agreement that has sometimes been described as TRIPS Plus [169,170]. While the final terms of the agreement are confidential, earlier leaked drafts indicated that Investor State Dispute Settlement (ISDS) formed a significant component. The ISDS provisions in regional free trade agreements allow enterprises to seek compensation through supranational arbitration from governments for official action (for example, restrictions in health or patent law) that result in substantive or potential losses. The mechanism could conceivably result in countries such as Australia modifying their legislation in order to harmonize with other major stakeholders in the area and minimize litigation. In the context of genetic patenting, the United States is the largest of the stakeholder members of the TPPA; it can be expected to advance the interests of its enterprises in order to secure domestic passage of the agreement, with minimal regard to the sovereignty and interests of other stakeholders [171-174]. 
A recurring theme throughout the judgements and the associated literature on proprietary and intellectual property rights in biological materials and derivative information and products is striking a balance between incentivizing research for utilitarian reasons and respecting human dignity [175-178].

Yet little of this debate has successfully rationalized why recognizing any rights - even non-economic ones, such as privacy — of donors is contrary to their dignity, noting that such arguments frequently focus exclusively on commodification, which is inherently commercial $[179,180]$. None of it provides a satisfactory explanation for the perception that researchers and biotech companies are so uncommitted to their goals that any additional ethical, legal, or regulatory burden - even one that did not involve recognizing financial claims brought by donors-would dissuade them from participation in markets worth billions of dollars.

This tension between protection of valuable commercial rights and the interests of donors is evident in the international legal instruments governing bioethics and genomics, intellectual property, and human rights. It is to this framework that readers should now turn their attention.

\section{An International Bioethics of the Informational Body?}

When it comes into effect, the TPPA will not be the only international legal instrument with potential implications for genetic privacy and donor and consumer rights. It may, however, be the only one that binds some member states.

Bioethics and human rights share a common genesis in the aftermath of the Nuremberg war trials. Prompted by an international sense that the atrocities perpetrated in Europe during World War II must never be repeated, the Universal Declaration of Human Rights and the Nuremberg Code were developed in response to the evidence presented at the war crimes trials [181].

The Nuremberg Code outlined 10 research ethics principles designed to govern experimentation on humans, including consent and voluntariness of participation, assessment of the risk as compared with the benefits, minimization of harm and discomfort to participants, and a rational empirical basis for the research. The code did not deal with property in body parts, use of cadavers, or the genome.

Subsequently incorporated into the Declaration of Helsinki, these principles remain the basis of much of the domestic legislation and professional codes of practice adopted around the world to govern the conduct of research on human subjects. As a product of the World Medical Association, the Declaration is not a legally binding international legal instrument per se; rather, its authority is indirect, relying on the extent to which it has been reflected in domestic laws and codes.

Bioethics and human rights clearly share a considerable degree of overlap, as is evident from the suite of three international legal instruments governing human biotechnology: the Universal Declaration on the Human Genome and Human Rights, the International Declaration on Human Genetic Data, and the Universal Declaration on Bioethics and Human Rights [182-184]. Each of the three instruments prioritizes respect for human dignity and human rights. The former two documents relate primarily to genetic information, while the latter is equally applicable to other forms of health information.

The Declaration on the Human Genome and Human Rights expressly does a number of things. Firstly, it categorically rejects reduction of individuals to manifestations of genetic characteristics, as inconsistent with recognition of the dignity of the individual (Article 2b). It prohibits the exploitation of the human genome "in its natural state" for commercial purposes (Article 4), and it privileges 
freedom of research and access to the benefits of that research (Articles 12b, 14-19). Importantly, however, it explicitly recognizes the right of the individual to choose whether or not they want to be informed of the results of genetic testing (Article 5c), requires that genetic data be treated with confidentiality (Article 7), and prohibits discrimination on the basis of genetic characteristics (Article 6) [182].

Similarly, the International Declaration on Human Genetic Data also requires that human identity not be reduced to the individual's genetic characteristics (Article 3), and prohibits discrimination and stigmatization on the basis of genetic data (Article 7). In addition, it acknowledges the predictive power of genetic data with respect to past, present, and future generations, as well as the special cultural significance attached to genetic information for some groups of people (Article 4); and recognizes the right of individuals, and their relatives, to choose whether or not they wish to be informed of the results of genetic testing (Article 10) [183].

Provisions within each of these documents can be inferred as disapproving of many of the judicial and legislative approaches adopted to genomic research described elsewhere in this article. In particular, the strong emphasis each instrument places on the adequacy of consent indicates that, from an international legal perspective at least, inadequate consent arrangements possibly warrant greater judicial sanction than they have received from the courts thus far.

\subsection{Informational Bodies in International Frameworks}

A contention in the preceding paragraphs is that emerging technologies such as DNA mapping/analysis and neuroscience are fostering a new "informational" conception of humans (and, by extension, other animals and organisms) - living things as manifestations of information, datasets, or abstractions rather than persons whose dignity is innate and inalienable [185-188]. Notwithstanding the rejection of this abstractionist approach under the international frameworks, it could be contended that this is essentially how those involved in collation of these datasets view donors. What are the consequences of a bioethics of "informational bodies", when people and communities are viewed as datasets rather than as flesh and blood that exhibits intelligence, manifests pain, elicits sympathy, or invokes guilt over disrespect, exploitation, and cruelty? Are existing high-level bioethics frameworks sufficiently capacious to deal with abstractions rather than people? Are research protocols, such as those used by institutional research boards in the United States and the National Health \& Medical Research Council in Australia, fit for purpose in dealing with ethical and legal dilemmas regarding large datasets?

One response to those questions is to refer to principles founded on respect for all people- $\mathrm{a}$ dignitarian approach - and to codes regarding the collection, use, dissemination, and disposal of information from or about human and animal research subjects [189-191]. The assumption is that we do not need to expressly refer to people as embodiments of data, given that researchers, clinicians, and other actors will address data conundrums by managing physical entities.

However, as discussed above, these principles are well enmeshed in the existing international bioethical framework, and reflected in domestic laws and codes of practice governing research. Is reference to dignity in instruments such as these sufficiently informative for researchers and others, or 
is the concept, which essentially underpins the whole premise of the international framework, too complex or devoid of meaning to be useful, as others have claimed [192]?

Debate, for example, regarding the commodification of blood (and blood products) is temperate [193]. Law regarding the ownership and exploitation of cadavers (e.g., through plastination), postmortem access to gametes, excised tissue, and unauthorized use of bones, teeth, and other body parts is increasingly settled [194-198]. Legislatures and courts are engaging with questions about gene patents and other intellectual property. More pertinently, codes founded on a nonmaleficence, or primum non nocere, principle recognize that harms may arise through inappropriate dissemination of sensitive information about an individual (for example, that person's immune status, medication regime, or psychiatric attributes) or unconscionable exploitation of that information. Education around implementation of those codes on a day-by-day basis acknowledges that some institutions, through routine, will drift to practice that privileges bureaucratic convenience over human dignity and that some clinicians or other individuals will become desensitized over time and accordingly treat patients as a symptom, a client, a billing item, or a research code [199].

That abstraction and hence disregard is likely to be salient in instances where consent by the subject is disregarded and where personhood is abstracted through a deidentification that is meant to both address concerns regarding privacy (in some instances, concerns founded in statute law) and facilitate an unbiased analysis of very large collections of data in order to produce social goods such as diagnostic/therapeutic tools for health problems such as cancer and schizophrenia. Does dealing with data, rather than directly with flesh and blood, mean that we can comfortably ignore Kant's exhortation to be respectful and not treat people as a means to an end [200]? If our conception of justice is based on Rawl's notion of fairness [201], should we be comfortable with gifting by public institutions of data that was collected on a compulsory basis or sale by those institutions at a price that grossly underestimates the data's value to the recipient?

\subsection{Questions about Big Data}

One example for considering those questions is the sale, and proposed sale, in the United Kingdom of population-scale health data acquired over several decades through National Health Service hospitals and medical practitioners. During the past three years the UK government has acknowledged that an agency sold - for what appears to have been only a few thousand pounds - "hospital event records" covering most hospital admissions in England over a twenty-year period [202-204]. The data were purchased by an insurance industry body and by marketers. Sale was defended on the basis that the data was deidentified, i.e., did not contain the names, phone numbers, residential addresses, and other identification attributes of individual patients. It was also defended on the basis that the dataset, in a standard electronic format, was the property of the agency rather than the patients - a defense that in the United Kingdom is legally correct. Regrettably, the deidentification was ineffective, with credible reports that the purchasers and associated were soon reidentifying data with a high degree of specificity. Controversy reflects disagreement about the feasibility of effective deidentification of data [205-208]. A necessary implication of the reidentification reports is that researchers can no longer make assurances to participants that data will never be reidentifiable, thereby seeking to rely on safe harbor-type legislative measures, without considering possible strategies for reidentification. 
Questions in the UK legislature and media about the sale preceded announcement by the Government of the ambitious care.data plan to provide access, on an exclusive or other basis, to whole-population data gained through patient interaction with medical practitioners [209]. The expectation was that pharmaceutical companies and other entities would have that access, promoted as boosting the United Kingdom into world leadership of life sciences research and resulting in cures for a range of medical problems [210]. As controversy grew, fostered by conflicting messages from officials and politicians, the government backtracked and indicated that patients would be able to opt out of the database [211]. There is ongoing contention about the ease of opting out [212,213].

There is little dispute that population-scale health data collections and genomic data collections are potentially very valuable tools for medical research. Access on a free or paid basis, exclusively or through a commons licensing regime, should not be dismissed out of hand [214]. From a bioethics perspective, however, we might question the care.data model. Should people be allowed to opt out, and to opt out of particular uses or retrospectively? Is a retrospective opt-out on a selective basis administratively feasible, a question that may arise as data subjects gain more information about particular uses of what they consider to be "their" data, or are sensitized through data breaches? Is provision of data without choice and without a sense of who will be using the data a condition of membership of civil society in the age of genomics, akin to an obligation to pay tax, serve on a jury, or serve in the armed forces during a time of military conflict? Is contention about the plan largely a matter of inept promotion and inadequate administration on the part of policymakers whose eyes are fixed on the greater good (and institutional aggrandizement) without much sense of community sensitivities? Will the use of bulk data be effectively protected under U.K. and other law, given concerns that officials misunderstand or disregard the ease of reidentification [215]? Should officials have an ethic of guardianship rather than ownership? Do mandatory data access programs erode the trust between clinician and patient that is fundamental to public health and enshrined in professional codes?

From both a legal and bioethics perspective that example should foster thought about the shape of privacy protection - and, by extension, respect for personhood-in an environment where there is increasing scope for data to move across institutional and jurisdictional boundaries, to be parsed without significant difficulty, and to be exploited without meaningful consent. There is a pressing need for a global privacy convention, in particular a convention that is expressly concerned with genomic privacy and that is given effect through justiciable statute law on a jurisdiction-by-jurisdiction basis.

\subsection{An International Privacy Framework, but Not Quite Yet?}

Concern about privacy is sometimes perceived as a purely modern, or even postmodern, phenomenon attributable to the emergence of surveillance devices such as closed circuit television cameras, the inescapable activity of intelligence agencies such as the U.S. National Security Agency, and comprehensive databases maintained by credit reference bodies, retailers, and direct marketers [216-220]. Although the focus of concerns has varied over time, the importance of privacy has been recognized in Anglo-Saxon law and civic culture since at least the Middle Ages [221], with common law regarding trespass and voyeur offences preceding landmark judgments about searches (such as Entick $v$. Carrington in 1765 [222]) and privacy provisions in early communications statutes dealing with mail, the telegraph, and telephone [223]. That protection of the private sphere from inappropriate 
interference by officials and members of the public has grown alongside the development of a comprehensive body of law concerned with particular relationships - for example, the confidentiality of information gained by medical practitioners in the course of health practice [224].

Respect for privacy as a facet of the private sphere is a feature of the foundational Universal Declaration of Human Rights and subsequent international human rights conventions, agreements to which there is a commitment by all advanced liberal democratic states [225]. At an abstract level it is axiomatic, a principle that is so accepted that it is often only formally recognized in instances where there is a conflict between competing interests. Such conflicts arise because for most ethicists privacy is not absolute; there are ethically and legally permissible erosions of the boundary between the private sphere and a more public life attributable to public administration, the exchange of information of political importance (as distinct from public curiosity), parental care for children, the delivery of health services, and so forth. One maxim for both lawyers and ethicists is that disrespect for the private sphere and thus for the dignity of an individual must be proportionate rather than, for example, determined by bureaucratic convenience.

Most nations have established formal privacy regimes, often given effect through a suite of disparate statutes [226]. Those statutes might be specific to particular activities, locations, or technologies (e.g., workplace privacy, restrictions on or authorization of closed-circuit television networks, census collections, public health records, searches of prison inmates and suspected criminals, and banking privacy). They might include one or more enactments that provide high-level coverage of informational privacy (e.g., the collection, use, and dissemination by public/private bodies of information supplied by consumers in the course of service provision by businesses and government agencies).

\subsection{Towards a Global Privacy Framework}

Although privacy is valorized through the key international human rights agreements, there is not a specific global privacy convention under the auspices of the United Nations, in contrast to the international copyright and industrial property conventions [227]. It is unlikely that a broad privacy convention will be developed in the near future, arguably because privacy (in contrast to intellectual property) is not seen to have a commercial value and because strengthened protection would be inconvenient for many government agencies, particularly in the law enforcement and national security sectors $[228,229]$. There have been proposals for international conventions that address particular privacy concerns: for example, unsuccessful calls for a global convention on genomic privacy [230].

Such a convention would serve two functions. Firstly it would signal to governments, business, and civil society advocates that genomic privacy is significant and should be expressly recognized through both statute law and practice protocols in each ratifying nation. Secondly, it would provide a discernible framework that is recognized in international law and given effect through the domestic law of the participating nations, irrespective of whether it is explicitly enshrined in a comprehensive bill/charter of rights on a nation—nation-basis [231].

From a bioethics perspective, such a convention appears more feasible, if not more desirable, than a new convention that seeks to enshrine a broad global right to health. In practice we are reliant on movement by the Organisation for Economic Co-operation \& Development (OECD) towards a non-mandatory global framework that centers on guidelines regarding health data. The OECD is 
significant because its 1980 Guidelines on the Protection of Privacy and Transborder Flows of Personal Data, in the development of which Australian jurist Michael Kirby was instrumental, influenced the shape of most national laws governing data protection. The guidelines center on informational privacy, seeking to encourage an appropriate balance between data use and the protection of personal privacy [232,233]. That balance is predicated on articulation of fair information principles covering data collection, data quality, purpose specification, use limitation, security safeguards, openness, individual participation, and accountability. It reflects the foundational value of individual autonomy in contemporary liberal democratic states [234]. It is, however, called into question by a realization that self-determination is potentially eroded by weak or absent awareness on the part of data subjects (for example, people who are contributing genomic samples to a direct-to-consumer genomics profiling enterprise or otherwise sharing their informational body with researchers) regarding what is done with their data and the consequences of that use. The OECD Guidelines predate smartphones, DTC genomic collections, health apps, and the wireless Internet [235]. It has become apparent over the past decade that there is an increasingly substantive need to address questions such as the creation of population-scale health databases (particularly those built around genomic data), access to such databases across borders, and the emergence of public-private sector "big science" partnerships in an environment where governments do not have the will, funds, or technical resources to independently drive life sciences research. New health-oriented guidelines are accordingly being developed by government, business, academic, and civil society representatives.

It is foreseeable that those guidelines, which will go beyond the 1980 framework, will be progressively reflected in national legislation and will sidestep the impasse evident in proposals under the auspices of United Nations bodies such as UNESCO [236,237]. What is less certain is whether the guidelines will articulate civil society expectations regarding genomic data (for example, in relation to a context-specific or more comprehensive opt-out or opt-in regime) and address dignitarian calls for institutions to conceptualize their activity as a trusteeship rather than ownership of data about people who are recipients of health services (or who, more broadly, are identifiable as relatives of those recipients) [238,239]. Will the guidelines foster a genomic commons, particularly a commons that is respectful of individual autonomy? Such a commons might ensure commercial enterprises accessing data assembled on a mandatory basis - through, for example, publicly funded national health schemes - return appropriate revenue to the community rather than engaging in rent seeking.

\subsection{Questions about Arbitrage and Ethics}

Should we be seeking an international framework? Is one feasible? Large-scale genetic testing services offered by commercial entities have a number of characteristics making such services appropriate targets for global regulation through international legal frameworks.

One characteristic is the globalized nature of the entities providing the services, which are commonly headquartered in one country but potentially with offshore data processing/storage capabilities and offer services to clients in a range of other countries that have diverse consumer protection statutes and inconsistent jurisprudence. The jurisdictional challenges for regulations imposed by these structures are further complicated by the use of the Internet as a marketing medium, and potential for cloud storage of sensitive and private data [240]. 
There are also significant ethical and human rights concerns raised by these services. There is a well-established international and domestic governance framework for research ethics undertaken on vulnerable populations, particularly minority groups and indigenous people. While those frameworks are not perfect (see, for example, the earlier discussion of Havasupai) they do provide a minimum standard for the conduct of ethical research, a standard underpinned by expectations regarding acceptability for publication in peer-reviewed journals and scrutiny by pharmaceutical regulators. Such research ethics frameworks (with their emphasis on respect for personhood and informed consent) are consistent with recognition of human rights through international treaties and declarations, including the Universal Declaration on Human Rights, the International Covenant on Civil \& Political Rights, International Covenant on Economic, Social \& Cultural Rights, and the Convention on the Rights of People with Disabilities. Human rights concerns of broader relevance are raised by the potential for discrimination against people on the basis of their genetics, made possible by weakly regulated genetic testing of those individuals or of their families. While there are some legislated protections against discrimination on the basis of genetics, such as the Genetic Information Non-discrimination Act (GINA) in the United States, and the provisions of the Disability Discrimination Act 1992 (Cth) in Australia, these protections are fragmented in both their scope and applicability, rather than coherent and ubiquitous in all jurisdictions in which genetic information is collected, stored, or utilized. We should be wary of the potential intergenerational consequences of participation, including the disregard of privacy of family members yet to be born and who are thus unable to provide their consent.

These concerns are well documented by international organizations including the OECD and the World Health Organization. They reflect concerns identified in reports noted above by advisory bodies such as the American Society for Human Genetics and the Nuffield Council on Bioethics, in the European legislatures, and in the Californian and New York state legislatures. Some jurisdictions have accordingly restricted the marketing of direct-to-consumer genomics, a restriction that is unlikely to be fully efficacious given the potential for regulatory arbitrage in global markets noted above. Other jurisdictions have been more permissive, with some restricting their official position on DTC genetic testing to the issuing of guidelines. Some - typically with weak consumer protection, health regulation, or privacy regimes - have simply not engaged with the issue at all, instead perceiving it as a case of caveat emptor (buyer beware), potentially further entrenching exploitation of uninformed consumers, including vulnerable groups.

\subsection{So What's Special about Genomics?}

The current patchwork of domestic laws regulating this global industry is not unique: similar arguments can be made about many areas of Internet-mediated globalized trade. However, none of those other areas has the same far-reaching human rights implications that direct-to-consumer genetic testing does. Buying a widget in one country from a company located elsewhere over the Internet is substantially different from providing a sample of your DNA, complete with extrapolatable information both about your relatives and descendants, on the basis of a poorly characterized, inadequately informed, or improperly obtained consent.

It is this unique combination of factors, rather than any one of them considered in isolation, which makes regulation of direct-to-consumer genetic testing services by commercial providers potentially 
occurring outside the framework of established research ethics review processes an appropriate subject for a binding international legal agreement.

\section{Conclusions}

This article has explored the relationship between traditional conceptions of personhood and property that are increasingly salient when applied to the informationalized body. In doing so, it has considered some of the unique challenges presented by genomic technology in the globalized world, including managing the intergenerationality of genomic data. It has also highlighted disagreements within health practitioner and medical research communities and uncertainties about the effectiveness of national regulation of genomic technology in a globalized world. The authors suggest that there is a need for the development of a truly globalized framework for regulating population-wide genomic data analysis, reflecting both potential benefits and harms.

Despite the existence of numerous international instruments reflecting bioethical concerns about exploitation of human genetic resources, and privacy, these instruments have no or limited legal effect until such time as nations sign up to them and incorporate them into their domestic laws. Countries are essentially picking and choosing which international agreements they want to be bound by. Unsurprisingly, we see a number of countries with strong commercial interests in biotechnology choosing to be bound by international legal frameworks designed to protect intellectual property rights, for example, which may well be at odds with competing instruments geared more towards protection of the donor or consumer, rather than commercial interests. In a globalized industry, therefore, there are significant risks to vulnerable people whose genetic information is commercially valuable, when exploited by researchers from companies or institutions in countries that are not necessarily bound by the same obligations as their own [241].

Domestic laws protecting privacy in general, and health and genetic privacy in particular, may be weak or unenforceable, even in countries with long-established regulatory machinery. Likewise, under-resourcing of agencies tasked with regulating the technology may result in issues at the intersection between various regulatory mechanisms - like privacy — falling through the gaps. Furthermore, privacy is often seen as a "weak" or "selfish" kind of right, one whose sacrifice is justifiable in the interests of public good. Utilitarian arguments such as these featured prominently in the wake of $9 / 11$ erosions to privacy laws throughout the western world. We have become accustomed to perceptions that privacy is a selfish expectation, secondary to other considerations such as contributing data that could potentially save lives. Indeed, in one jurisdiction (Australia) the national Privacy Act has been amended to permit doctors to disclose genetic information to relatives without the patient's consent if that information reveals risk of that relative developing a serious disease. There are indications that other jurisdictions are considering similar measures.

It is clear that many people have a willingness, altruistic or otherwise, to share their informational body - through provision of genomic samples - to advance medical science. Health service administrators are also enthusiastic about the scope for fostering public health through the sharing of health records and facilitation of large-scale genomic databases, an enthusiasm that is not necessarily linked to the scope for the sort of revenue generation evident in the NHS and care.data sales highlighted above. Some people may be aware of concerns regarding potential misuse of genomic information and tissue. 
Others may not, or may place personal interests (with, for example, a discourse of self-fashioning and self-awareness) ahead of the interests of their current and future relatives [242].

Regardless of their motivations for sharing their informational body, it is imperative that donors' decisions are based on appropriate consideration of the implications of that decision, both for themselves and others who may have a common interest in that informational body, on the basis of shared genetic heritage. Necessary to that consideration is the provision of sufficient information to identify the risks and benefits of the research, potentially on an ongoing basis, reflecting the immortality of the informational body as distinct from the finite and limited lifespan of the physical body.

The reliability and utility of large-scale genetic testing technologies may — and probably will—increase. However, investing substantial public resources without adequate consideration of the underlying risks to consumers and donors risks entrenching healthcare inequality even further. We should seek to avoid a world in which donors will continue to be treated as little more than means to ends, their genomes strip-mined for whatever data they can yield without consideration for the consequences; unrestricted commercialization will result in erection of economic barriers to diagnostics and treatments, where healthcare is for the privileged rather than a basic right. Lawmakers and policymakers need to address these issues sooner rather than later: once unlocked, genomic information is out there, infinitely replicable, and potentially open to all.

One option to achieve this is for the international community to begin negotiating an international standard regarding regulation of genetic privacy. While international treaties and conventions are not infallible, they do at least provide a guiding norm, and could potentially do much to address the emerging global arbitrage of this technology. At a minimum, they would demonstrate awareness by policymakers of some of the potential risks to consumers of failing to consider — at a policy level — the implications of population-scale trading in health and genetic-linked data. Failure to do so will result in a multi-track system, whereby conflicting international norms are by default established by particular stakeholders, and consumers are left unprotected to fall into the gaps.

\section{Author Contributions}

The co-authors contributed equally to the research and writing of this article.

\section{Conflicts of Interest}

The authors declare no conflict of interest.

\section{Abbreviations}

DTC: Direct-to-consumer;

TPPA: Trans Pacific Partnership Agreement;

FDA: Food and Drug Administration;

EMBL: European Molecular Biology Laboratory. 


\section{References and Notes}

1. David Lazer. "Introduction." In DNA and the Criminal Justice System: The Technology of Justice. Edited by David Lazer. Cambridge: The MIT Press, 2004, pp. 1-13.

2. Sheldon Krimsky, and Tania Simoncelli. Genetic Justice: DNA Data Banks, Criminal Investigations, and Civil Liberties. New York: Columbia University Press, 2013.

3. Kimberly TallBear. "DNA and Native American Identity." International Journal of Cultural Property 16 (2009): 189-92.

4. Ugo Perego, Ann Turner, Jayne E. Ekins, and Scott R. Woodward. "The science of molecular genealogy." National Genealogical Society Quarterly 93 (2005): 245-59.

5. Dennis O'Rourke. "Anthropological genetics in the genomic era: A look back and ahead." American Anthropologist 105 (2003): 101-9.

6. Ngaire Naffine. "Legal personality and the natural world: On the persistence of the human measure of value." Journal of Human Rights and the Environment 30 (2012): 68-83.

7. Margaret Radin. "Property and personhood." Stanford Law Review 34 (1982): 957-1016.

8. Alasdair MacIntyre. Dependent Rational Animals: Why Human Beings Need The Virtues. Chicago: Open Court, 1999.

9. Ngaire Naffine. "Who Are Law's Persons? From Cheshire Cats to Responsible Subjects." Modern Law Review 66 (2003): 346-67.

10. Michael Rivard. "Toward a General Theory of Constitutional Personhood: A Theory of Constitutional Personhood for Transgenic Humanoid Species." UCLA Law Review 39 (1991): $1425-510$.

11. William Blackstone. Commentaries on the Laws of England: Vol II- "Of Things". Oxford: Clarendon Press, 1766, p. 429.

12. Donna Dickenson. Property in the Body: Feminist Perspectives. Cambridge: Cambridge University Press, 2007.

13. Haynes Case (7 Coke 113).

14. Rv Lynn (2 Term R 733).

15. Doodeward v Spence (1908) 6 CLR 406.

16. Alexandra George. "The Difficulty of Defining 'Property'." Oxford Journal of Legal Studies 25 (2005): 793-813.

17. David Winickoff. "Partnership in UK Biobank: A third way for genomic property?" The Journal of Law, Medicine \& Ethics 35 (2007): 440-56.

18. Kevin Davies. The \$1,000 Genome: The Revolution in DNA Sequencing and the New Era of Personalized Medicine. New York: Simon and Schuster, 2010.

19. Richard Tutton. Genomics and the Reimagining of Personalized Medicine. Aldershot: Ashgate, 2014.

20. Martha Fineman. "The vulnerable subject: Anchoring equality in the human condition." Yale Journal of Law \& Feminism 20 (2008): 8-40.

21. Alice Ristroph. "Criminal Law for Humans." In Hobbes and the Law. Edited by David Dyzenhaus and Thomas Poole. Cambridge: Cambridge University Press, 2014, pp. 97-112.

22. Jenny Reardon. Race to the Finish: Identity and Governance in an Age of Genomics. Princeton: Princeton University Press, 2009. 
23. Richard Dawkins. The Selfish Gene. Oxford: Oxford University Press, 1976.

24. Errol Friedberg. "DNA damage and repair." Nature 421 (2003): 436-40.

25. Puping Liang, Yanwen Xu, Xiya Zhang, Chenhui Ding, Rui Huang, Zhen Zhang, Jie Lv, Xiaowei Xie, Yuxi Chen, Yujing Li, and et al. "CRISPR/Cas9-mediated gene editing in human tripronuclear zygotes." Protein \& Cell 6 (2015): 363-72.

26. Edward Lanphier, Fyodor Urnov, Sarah Ehlen Haecker, Michael Werner, and Joanna Smolenski. "Don't edit the human genome." Nature 519 (2015): 410-11.

27. Rene Almeling. "Selling genes, selling gender: Egg agencies, sperm banks, and the medical market in genetic material." American Sociological Review 72 (2007): 319-40.

28. Gary Marchant. "Genetic Data in Toxic Tort Litigation.” Journal of Law \& Policy 14 (2006): 7-37.

29. Larry Gostin. "Genetic discrimination: The use of genetically based diagnostic and prognostic tests by employers and insurers." American Journal of Law \& Medicine 17 (1991): 109-44.

30. Janneke Gerards, Aalt Willem Heringa, and Heleen Janssen. Genetic Discrimination and Genetic Privacy in a Comparative Perspective. Antwerp: Intersentia, 2005.

31. United Nations Convention against Transnational Organized Crime (UNTOC). "Protocol to Prevent, Suppress and Punish Trafficking in Persons, Especially Women and Children.” 2000. Available online: http://www.ohchr.org/EN/ProfessionalInterest/Pages/ProtocolTraffickingInPersons.aspx (accessed on 28 July 2015).

32. Peter Drahos. A Philosophy of Intellectual Property. Aldershot: Dartmouth, 1996.

33. World Trade Organization. "Trade-Related Aspects of Intellectual Property Rights (Annex 1C of the Marrakesh Agreement Establishing the World Trade Organization)." 15 April 1994. Available online: https://www.wto.org/english/tratop_e/trips_e/t_agm0_e.htm (accessed on 28 July 2015).

34. Francis Collins, and Harold Varmus. "A new initiative on precision medicine." New England Journal of Medicine 372 (2015): 793-95.

35. Reza Mirnezami, Jeremy Nicholson, and Ara Darzi. "Preparing for precision medicine." New England Journal of Medicine 366 (2012): 489-91.

36. Sheryl Hamilton. Impersonations: Troubling the Person in Law and Culture. Toronto: University of Toronto Press, 2013.

37. Margaret Davies, and Ngaire Naffine. Are Persons Property? Legal Debates about Property and Personality. Aldershot: Ashgate, 2001.

38. David C. Thomasma, David N. Weisstub, and Christian Hervé, eds. Personhood and Health Care. Berlin: Springer, 2001.

39. Sheila Shaver. "Body rights, social rights and the liberal welfare state." Critical Social Policy 13 (1994): 66-93.

40. Thomas Finegan. "Conceptual Foundations of the Universal Declaration of Human Rights: Human Rights, Human Dignity and Personhood." Australian Journal of Legal Philosophy 37 (2012): 182-218.

41. Lyman Johnson. "Law and Legal Theory in the History of Corporate Responsibility: Corporate Personhood.” Seattle University Law Review 35 (2012): 1135-64.

42. Adam Winkler. "Corporate Personhood and the Rights of Corporate Speech." Seattle University Law Review 30 (2007): 863-73.

43. Peter Singer. “Animal liberation or animal rights?” The Monist 70 (1987): 3-14. 
44. Stephen Wise. Rattling the Cage: Toward Legal Rights for Animals. Cambridge: Perseus Books, 2000.

45. Taimie Bryant. "Sacrificing the Sacrifice of Animals: Legal Personhood for Animals, the Status of Animals as Property, and the Presumed Primacy of Humans." Rutgers Law Journal 39 (2007): 247-330.

46. Muireann Quigley. "Propertisation and Commercialisation: On Controlling the Uses of Human Biomaterials." The Modern Law Review 77 (2014): 677-702.

47. James Scott. Seeing like a State: How Certain Schemes to Improve the Human Condition Have Failed. New Haven: Yale University Press, 1998.

48. Immanuel Kant. "Groundwork of the Metaphysics of Morals (Grundlegung zur Metaphysik der Sitten)." In Practical Philosophy (The Cambridge Edition of the Works of Immanuel Kant). Translated by Mary Gregor. Cambridge: Cambridge University Press, 1999, p. 79.

49. National Commission for the Protection of Human Subjects of Biomedical and Behavioral Research. Belmont Report: Ethical Principles and Guidelines for the Protection of Human Subjects of Research. Washington: United States Government Printing Office, 1978.

50. World Medical Association. "Declaration of Helsinki." 1964. Available online: http://www.wma.net/en/30publications/10policies/b3/ (accessed on 28 July 2015).

51. President's Commission for the Study of Bioethical Issues. "Privacy and Progress in Whole Genome Sequencing." 2012. Available online: http://bioethics.gov/sites/default/files/Privacy Progress508_1.pdf (accessed on 28 July 2015).

52. Nuffield Council on Bioethics. "The Collection, Linking and Use of Data in Biomedical Research and Health Care: Ethical Issues.” 2015. Available online: http://nuffieldbioethics.org/ wp-content/uploads/Biological_and_health_data_web.pdf (accessed on 28 July 2015).

53. Human Genome Organisation. "Bermuda Principles." 1996. Available online: http://www.casimir.org.uk/storyfiles/64.0.summary_of_bermuda_principles.pdf (accessed on 28 July 2015).

54. National Health \& Medical Research Council. "National Statement on Ethical Conduct in Human Research." 2007. Available online: http://www.nhmrc.gov.au/_files_nhmrc/file/ publications/synopses/e72-jul09.pdf (accessed on 28 July 2015).

55. Samuel Warren, and Louis Brandeis. "The Right to Privacy." Harvard Law Review 4 (1890): 193-220.

56. Helen Nissenbaum. Privacy in Context: Technology, Policy, and the Integrity of Social Life. Stanford: Stanford University Press, 2009.

57. Lee Bygrave. Data Protection Law: Approaching its Rationale, Logic and Limits. New York: Kluwer Law, 2002, p. 128.

58. United Nations General Assembly. "Universal Declaration of Human Rights.” 1948. Available online: http://www.ohchr.org/EN/UDHR/Documents/UDHR_Translations/eng.pdf (accessed on 28 July 2015).

59. United Nations General Assembly. "International Covenant on Civil and Political Rights." 1966. Available online: http://www.ohchr.org/en/professionalinterest/pages/ccpr.aspx (accessed on 28 July 2015). 
60. United Nations General Assembly. "Convention on the Rights of the Child." 1989. Available online: http://www.ohchr.org/en/professionalinterest/pages/crc.aspx (accessed on 28 July 2015).

61. Tanya Aplin, Lionel Bently, Philip Johnson, and Simon Malynicz. Gurry on Breach of Confidence, 2nd ed. Oxford: Oxford University Press, 2012.

62. Health Insurance Portability and Accountability Act of 1996 (US).

63. Privacy Act 1988 (Cth).

64. Privacy Act 1993 (NZ).

65. Health Records and Information Privacy Act 2002 (NSW).

66. For example Hopkins v. Kay 2015 ONCA 112.

67. Concetta Di Iorio, Fabrizio Carinci, and Jillian Oderkirk. "Health research and systems' governance are at risk: Should the right to data protection override health?" Journal of Medical Ethics 40 (2014): 488-92.

68. Dara Hallinan, and Michael Friedewald. "Open consent, biobanking and data protection law: can open consent be 'informed' under the forthcoming data protection regulation?" Life Sciences, Society and Policy 11 (2015): 1-36.

69. See for example See Vidal-Hall v Google Inc [2014] EWHC 13 (QB); Weller \& Ors v Associated Newspapers Ltd [2014] EWHC 1163 (QB); Jones v. Tsige, 2012 ONCA 32 and Equustek Solutions Inc. v. Jack [2014] BCSC 1063.

70. Graham Greenleaf. Asian Data Privacy Laws: Trade and Human Rights Perspectives. Oxford: Oxford University Press, 2014.

71. Christopher Kuner. European Data Protection Law, Corporate Compliance and Regulation. Oxford: Oxford University Press, 2007.

72. Paul Schwartz, and Daniel J. Solove. "Reconciling Personal Information in the United States and European Union." California Law Review 102 (2014): 877-916.

73. Hakon Hakonarson, and Struan F. A. Grant. "Planning a genome-wide association study: Points to consider." Annals of Medicine 43 (2011): 451-60.

74. Steve Connor. "Genetic Test could pave the way for breast cancer "magic bullets'." The Independent." 19 April 2012. Available online: http://www.independent.co.uk/news/science/ genetic-test-could-pave-the-way-for-breast-cancer-magic-bullets-7658168.html (accessed on 28 July 2015).

75. Troy Duster. "A post-genomic surprise. The molecular reinscription of race in science, law and medicine." The British Journal of Sociology 66 (2015): 1-27.

76. Research \& Markets Inc. "In Vitro Diagnostic (IVD) Market, Technique \& Applications - Forecast to 2017." 2013. Available online: http://www.researchandmarkets.com/reports/2618982/in vitro_diagnostic_ivd_market_technique_and (accessed on 28 July 2015).

77. Nicolas Rasmussen. Gene Jockeys: Life Science and the Rise of Biotech Enterprise. Baltimore: Johns Hopkins University Press, 2014.

78. Lori Andrews, and Jordan Paradise. "Gene patents: The need for bioethics scrutiny and legal change." Yale Journal of Health Policy Law \& Ethics 5 (2005): 403-12.

79. Sandra Park. "Gene Patents and the Public Interest: Litigating Association for Molecular Pathology v. Myriad Genetics and Lessons Moving Forward." North Carolina Journal of Law and Technology 15 (2014): 519-36. 
80. Tom Andreassen. "Ethical reasons for narrowing the scope of biotech patents." Medicine, Health Care and Philosophy May (2015): 1-11.

81. White House. "President Clinton Announces The Completion of the First Survey of the Entire Human Genome, Hails Public and Private Efforts Leading to This Historic Achievement." 25 June 2000. Available online: http://archive.hhs.gov/news/press/2000pres/20000626.html (accessed on 28 July 2015).

82. International Human Genome Sequencing Consortium. "Initial sequencing and analysis of the human genome." Nature 409 (2001): 860-921.

83. J. Craig Venter, Mark D. Adams, Eugene W. Myers, Peter W. Li, Richard J. Mural, Granger G. Sutton, Hamilton O. Smith, Mark Yandell, Cheryl A. Evans, Robert A. Holt, and et al. "The sequence of the human genome." Science 291 (2001): 1304-51.

84. The germ cells (sperm and egg) only contain half the nuclear DNA complement; other cell types, including red blood cells, do not contain nuclear DNA.

85. Francis Collins. "Medical and societal consequences of the human genome project." New England Journal of Medicine 341 (1999): 28-37.

86. Jay Shendure, and Hanlee Ji. "Next-generation DNA sequencing." Nature Biotechnology 26 (2008): 1135-42.

87. Ferdouse Begum, Debashis, George Ghosh Tseng, and Eleanor. Feingold. "Comprehensive literature review and statistical considerations for GWAS meta-analysis." Nucleic Acids Research 40 (2012): 3777-84.

88. Lin Hou, and Hongyu Zhao. "A review of post-GWAS prioritization approaches: Article 280.” 2013. Available online: http://www.ncbi.nlm.nih.gov/pmc/articles/PMC3856625/pdf/fgene-04-00280.pdf (accessed on 28 July 2015).

89. Alkes Price, Noah Zaitlen, David Reich, and Nick Patterson. "New approaches to population stratification in genome-wide association studies." Nature Review Genetics 11 (2010): 459-63.

90. Gregory Cooper, and Jay Shendure. "Needles in stacks of needles: Finding disease-causal variants in a wealth of genomic data." Nature Review Genetics 12 (2011): 628-40.

91. Genetics and Public Policy Center. "GPCC releases updated list of DTC genetic testing companies." 2011. Archived media release available online: https://web.archive.org/web/ 20150209133049/http://dnapolicy.org/news.release.php?action=detail\&pressrelease_id=145 (accessed on 28 July 2015).

92. Richard Spinello. "Property rights in genetic information." Ethics and Information Technology 6 (2004): 29-42.

93. Herman Tavani. "Genomic research and data-mining technology: Implications for personal privacy and informed consent." Ethics and Information Technology 6 (2004): 15-28.

94. Jeantine Lunshof, Ruth Chadwick, Daniel Vorhaus, and George Church. "From genetic privacy to open consent." Nature Reviews Genetics 9 (2008): 406-11.

95. Ruha Benjamin. "A lab of their own: Genomic sovereignty as postcolonial science policy." Policy and Society 28 (2009): 341-55.

96. Stefan Helmreich. "Species of biocapital." Science as Culture 17 (2008): 463-78.

97. Kaushik Rajan, ed. Lively Capital: Biotechnologies, Ethics, and Governance in Global Markets. Durham: Duke University Press, 2012. 
98. Michael Fortun. Promising Genomics: Iceland and deCODE Genetics in a World of Speculation. Berkeley: University of California Press, 2008.

99. Gisli Palsson, and Paul Rabinow. "Iceland: The case of a national human genome project." Anthropology Today 15 (1999): 14-18.

100. Ruth Chadwick. "The Icelandic database-Do modern times need modern sagas?" British Medical Journal 319 (1999): 441-44.

101. Alison Abbott. "Icelandic database shelved as court judges privacy in peril." Nature 429 (2004): 118.

102. Renate Gertz. "An analysis of the Icelandic Supreme Court judgement on the Health Sector Database Act." SCRIPTed 1 (2004): 241-58.

103. David Winickoff. "A Bold Experiment: Iceland's Genomic Venture." In Ethics, Law and Governance of Biobanking. Edited by Deborah Mascalzoni. Dordrecht: Springer Netherlands, 2015, pp. 187-209.

104. International Human Genome Sequencing Consortium (IHGSC). "Finishing the euchromatic sequence of the human genome." Nature 431 (2004): 931-45.

105. Paolo Vineis, and David C. Christiani. "Genetic testing for sale." Epidemiology 15 (2004): 3-5.

106. Pascal Ducournau, and Claire Beaudevin. "Of deterritorialization, healthism and biosocialities: The companies' marketing and users' experiences of online genetics." Journal of Science Communication 10 (2011): 1-9.

107. Jennifer Wagner, Jill D. Cooper, Rene Sterling, and Charmaine D. Royal. "Tilting at windmills no longer: A data-driven discussion of DTC DNA ancestry tests." Genetics in Medicine 14 (2012): 586-93.

108. Pascal Borry, Martina C. Cornel, and Heidi C. Howard. "Where are you going, where have you been: A recent history of the direct to consumer genetic testing market." Journal of Community Genetics 1 (2010): 101-6.

109. Jane Kaye. "The regulation of direct to consumer genetic tests." Human Molecular Genetics 17 (2008): R180-83.

110. Gabrielle Samuel, Christopher F. C. Jordens, and Ian Kerridge. "Direct to consumer personal genome testing: Ethical and regulatory issues that arise from wanting to 'know' your DNA." Internal Medicine Journal 40 (2010): 220-24.

111. Alison Harvey. "Genetic risks and healthy choices: Creating citizen-consumers of genetic services through empowerment and facilitation." Sociology of Health \& Illness 32 (2010): 365-81.

112. Leslie Pray. "DTC Genetic testing: 23andme, DNA Direct and Genelex." Nature Education 1 (2008): 22.

113. Misha Angrist. "We are the genes we've been waiting for: Rational responses to the gathering storm of personal genomics." The American Journal of Bioethics 9 (2009): 30-31.

114. Allen Salkin. "When in doubt, spit it out." New York Times, 12 September 2008. Available online: http://www.nytimes.com/2008/09/14/fashion/14spit.html?_r=0 (accessed on 28 July 2015).

115. Gert van Ommen, and Martina Cornel. "Recreational genomics? Dreams and fears of genetic susceptibility screening." European Journal of Human Genetics 16 (2008): 403-4.

116. Christine Patch, Jorge Sequeiros, and Martina Cornel. "Genetic horoscopes: Is it all in the genes? Points for regulatory control of direct to consumer genetic testing." European Journal of Human Genetics 17 (2009): 857. 
117. J. Scott Roberts, and Jenny Ostergren. "Direct to consumer genetic testing and personal genomics services: A review of recent empirical studies." Current Genetic Medicine Reports 1 (2013): 182-200.

118. Michael Murray. "Why We Should Care About What You Get for 'Only $\$ 99$ ' from a Personal Genomic Service.” Annals of Internal Medicine 160 (2014): 507-8.

119. Rachel Kalf, Rachel Bakker, and Cecile Janssens. "Predictive ability of direct to consumer pharmacogenetic testing: When is lack of evidence really lack of evidence?" Pharmacogenomics 14 (2013): 341-44.

120. Jon Merz, Antigone Kriss, Debra Leonard, and Mildred Cho. "Diagnostic testing fails the test." Nature 415 (2002): 577-99.

121. Stacey Adams, James Evans, and Arthur Aylsworth. "Direct to consumer genomic testing offers little clinical utility but appears to cause minimal harm." North Carolina Medical Journal 74 (2013): 494-98.

122. Gregory Kutz. "Direct to consumer Genetic Tests: Misleading Test Results Are Further Complicated by Deceptive Marketing and Other Questionable Practices-Testimony. Before the Subcommittee on Oversight and Investigations, Committee on Energy and Commerce, House of Representatives." U.S. Government Accountability Office, 2010. Available online: http://www.gao.gov/assets/130/125079.pdf (accessed on 27 July 2015).

123. Alberto Gutierrez. "Warning Letter (Correspondence from US Food and Drug Administration to providers of DTC genetic testing)." 2013. Available online: http://www.fda.gov/ICECI/ EnforcementActions/WarningLetters/2013/ucm376296.htm (accessed on 28 July 2015).

124. Amy McGuire, Barbara J. Evans, Timothy Caulfield, and Wylie Burke. "Regulating direct to consumer personal genome testing." Science 330 (2010): 181-82.

125. Stuart Hogarth, Gail Javitt, and David Melzer. "The current landscape for direct to consumer genetic testing: Legal, ethical, and policy issues." Annual Review of Genomics and Human Genetics 9 (2008): 161-82.

126. Amy McGuire, and Wylie Burke. "An unwelcome side effect of direct to consumer personal genome testing: Raiding the medical commons." Journal of the American Medical Association 300 (2008): 2669-71.

127. Greg Gibson, and Gregory P. Copenhaver. "Consent and Internet-Enabled Human Genomics." PLoS Genetics 6 (2010): e1000965.

128. Pascal Su. "Direct to consumer Genetic Testing: A Comprehensive View." Yale Journal of Biology \& Medicine 86 (2013): 359-65.

129. White House. "Fact Sheet: President Obama's Precision Medicine Initiative." 2015. Available online: https://www.whitehouse.gov/the-press-office/2015/01/30/fact-sheet-president-obama-sprecision-medicine-initiative (accessed on 28 July 2015).

130. National Health Service. "NHS set to deliver world-leading genomics project in fight against cancer and rare diseases." 2014. Available online: http://www.england.nhs.uk/2014/12/22/ genomics-project/ (accessed on 28 July 2015).

131. Anna Pokorska-Bocci, Mark Kroese, Gurdeep Sagoo, Alison Hall, and Hilary Burton. "Personalised medicine in the UK: Challenges of implementation and impact on healthcare system." Genome medicine 6 (2014): 28-47. 
132. Bartha Knoppers. "Genomics and policymaking: From static models to complex systems?" Human Genetics 125 (2009): 375-79.

133. Bruce Baer Arnold, and Wendy Bonython. "Sharing the Book of Life: Privacy, the new genomics and health sector managers." Privacy Law Bulletin 12 (2015): 9-14.

134. John Knott. "Popular attitudes to death and dissection in early nineteenth century Britain: The anatomy act and the poor." Labour History 49 (1985): 1-18.

135. Marett Leiboff. “A Beautiful Corpse.” Continuum: Journal of Media \& Cultural Studies 19 (2005): 221-37.

136. Patents Act 1990 (Cth) s 7; Patents Act 1977 (UK) s 2; Patents Act 2013 (NZ) s 6.

137. Sean Seymore. "Rethinking Novelty in Patent Law." Duke Law Journal 60 (2011): 919-76.

138. David Vaver. "Invention in patent law: A review and a modest proposal." International Journal of Law and Information Technology 11 (2003): 286-307.

139. The sizeable body of jurisprudence from Australia, the UK and the USA on retrieval, storage and use of sperm belonging to deceased men provides a clear illustration of this lack of coherence. See e.g., Kate Jane Bazley v Wesley Monash IVF Pty Ltd [2010] QSC 118; Jocelyn Edwards; Re the estate of the late Mark Edwards [2011] NSWSC 478; cf. Yearworth v North Bristol NHS Trust [2009] EWCA Civ 37.

140. Radhika Rao. "Genes and spleens: Property, contract, or privacy rights in the human body?" The Journal of Law, Medicine \& Ethics 35 (2007): 371-82.

141. A.M. Honore. "Ownership." In Oxford Essays in Jurisprudence. Edited by Anthony Guest. Oxford: Oxford University Press, 1961, pp. 107-8.

142. Ralph Newman. Equity and Law: A Comparative Study. New York: Oceana, 1961, p. 11.

143. Jacques de Werra. Research Handbook on Intellectual Property Licensing. Cheltenham: Edward Elgar, 2013.

144. Neville Crago. "Principles of disclaimer of gifts." Western Australia Law Review 28 (1999): 65-83.

145. Rebecca Skloot. The Immortal Life of Henrietta Lacks. New York: Crown Books, 2010.

146. Jonathan Landry, Paul Theodor Pyl, Tobias Rausch, Thomas Zichner, Manu Tekkedil, Adrian Stütz, Anna Jauch, Raeka Aiyar, Gregoire Pau, Nicolas Delhomme, and et al. "The genomic and transcriptomic landscape of a HeLa cell line." G3: Genes/Genomes/Genetics 3 (2013): 1213-24.

147. Ewan Callaway. "Deal done over HeLa cell line." Nature 8 (2013):132-33.

148. Rebecca Skloot. "The Immortal Life of Henrietta Lacks, the Sequel.” New York Times, 23 March 2013. Available online: http://www.nytimes.com/2013/03/24/opinion/sunday/the-immortal-lifeof-henrietta-lacks-the-sequel.html (accessed on 28 July 2015).

149. Kathy Hudson, and Francis Collins. "Biospecimen policy: Family matters." Nature 500 (2013): 141-42.

150. Laura Rowe. "You Don't Own Me: Recommendations to Protect Human Contributors of Biological Material after Washington University v. Catalona." Chicago-Kent Law Review 84 (2009): 250.

151. Moore $v$ Regents of the University of California 51 Cal. 3d 120, 271 Cal. Rptr. 146, 793 P.2d 479, cert. denied 499 U.S. 936 (1991).

152. Greenberg v Miami Children's Hospital Research Institute 264 F. Supp. 2d 1064 (S.D. Fla. 2003).

153. Washington University v Catalona, 437 F. Supp. 2d 985, 1002 (E.D. Mo. 2006). 
154. Havasupai Tribe v Arizona State University Board of Regents 204 P.3d 1063, 1070 (Ariz. Ct. App. 2008).

155. Michelle Mello, and Leslie E. Wolf. "The Havasupai Indian Tribe Case-Lessons for Research Involving Stored Biologic Samples.” The New England Journal of Medicine 363 (2010): 204-7.

156. Maureen Dorney. "Moore v. The Regents of the University of California: Balancing the need for biotechnology innovation against the right of informed consent." High Technology Law Journal 5 (1989): 333-69.

157. Lori Andrews. "Who owns your body? A patien's perspective on Washington University v. Catalona." The Journal of Law, Medicine \& Ethics 34 (2006): 398-407.

158. Washington University v Catalona, 490 F3d 667 (8th Cir 2007).

159. Robyn Sterling. "Genetic Research among the Havasupai-A Cautionary Tale." Virtual Mentor 13 (2011): 113-17.

160. Katherine Drabiak-Syed. "Lessons from Havasupai Tribe v Arizona State University Board of Regents: Recognizing Group, Cultural, and Dignitary Harms as Legitimate Risks Warranting Integration into Research Practice." Journal of Health \& Biomedical Law 6 (2010): 175-225.

161. Judy Allen, D’Arcy Holman, Eric M Meslin, and Fiona Stanley. "Privacy protectionism and health information: Is there any redress for harms to health?" Journal of Law and Medicine 21 (2013): 473-85.

162. Jennifer Harris, Paul Burton, Bartha Knoppers, Klaus Lindpaintner, Marianna Bledsoe, Anthony Brookes, Isabelle Budin-Ljøsne, Rex Chisholm, David Cox, Mylène Deschênes, and et al. "Toward a roadmap in global biobanking for health." European Journal of Human Genetics 20 (2012): 1105-11.

163. D. Gareth Jones. "Genetic privacy and the use of archival human material in genetic studies_current perspectives." Medicolegal \& Bioethics 5 (2015): 43-52

164. Bernice Elger. Ethical Issues of Human Genetic Databases: A Challenge to Classical Health Research Ethics? Aldershot: Ashgate, 2013.

165. Association for Molecular Pathology v. Myriad Genetics Inc 569 U.S. 12-398 (2013).

166. [2013] FCA 65.

167. Claire Gregg. "The Myriad Dichotomy: A tale of two jurisdictions." Intellectual Property Forum: Journal of the Intellectual and Industrial Property Society of Australia and New Zealand 99 (2014): 21-35.

168. Brad Sherman. "Before The High Court: D’Arcy v Myriad Genetics Inc.: Patenting Genes in Australia." Sydney Law Review 37 (2015): 135-47.

169. Susy Frankel. "Challenging TRIPS-plus agreements: The potential utility of non-violation disputes." Journal of International Economic Law 12 (2009): 1023-65.

170. Henning Grosse Ruse-Khan. "The international law relation between TRIPS and subsequent TRIPS-Plus free trade agreements: Towards safeguarding TRIPS flexibilities?” Journal of Intellectual Property Law 18 (2011): 1.

171. Christopher Arup. "The Governance of Patents and Pharmaceuticals: The Regional FTA Contribution." In Intellectual Property and Free Trade Agreements in the Asia-Pacific Region. Edited by Christoph Antons and Reto Hilty. Berlin: Springer, 2015, pp. 287-313. 
172. Thomas A. Faunce. "Challenges to Australia's national health policy from trade and investment agreements." Medical Journal of Australia 196 (2012): 354-56.

173. Ruth Lopert, and Deborah Gleeson. "The High Price of 'Free' Trade: U.S. Trade Agreements and Access to Medicines." The Journal of Law, Medicine \& Ethics 41 (2013): 199-223.

174. Ruth Okediji. "Is Intellectual Property Investment: Eli Lilly v. Canada and the International Intellectual Property System.” Journal of International Law 35 (2013): 1121-38.

175. James Bessen, and Michael Meurer. Patent Failure: How Judges, Bureaucrats, And Lawyers Put Innovators at Risk. Princeton: Princeton University Press, 2008.

176. John P. Walsh, Ashish Arora, and Wesley M. Cohen. "Effects of Research Tool Patents and Licensing on Biomedical Innovation." In Patents in the Knowledge-Based Economy. Edited by Wesley M. Cohen and Stephen A. Merrill. Washington: The National Academies Press, 2003, pp. 285-335.

177. Michael Heller, and Rebecca S. Eisenberg. "Can Patents Deter Innovation? The Anticommons in Biomedical Research.” Science 280 (1998): 698-701.

178. Dianne Nicol, Jane Neilsen, Johnathan Liddicoat, Christine Critchley, and Tess Whitton. "The Innovation Pool in Biotechnology: The Role of Patents in Facilitating Innovation." 2014. Available online: http://ssrn.com/abstract=2503314 (accessed on 28 July 2015).

179. Philippe Steiner. "Gifts of blood and organs: The market and 'fictitious' commodities." Revue Française de Sociologie 44 (2003): 147-62.

180. Iain McLean, and Jo Poulton. "Good blood, bad blood, and the market: The gift relationship revisited.” Journal of Public Policy 6 (1986): 431-45.

181. George Annas, and Michael Grodin, eds. The Nazi Doctors and the Nuremberg Code: Human Rights in Human Experimentation: Human Rights in Human Experimentation. New York: Oxford University Press, 1991.

182. United Nations Educational. "Scientific and Cultural Organization Universal Declaration on the Human Genome and Human Rights.” 1997. Available online: http://www.unesco.org/new/en/ social-and-human-sciences/themes/bioethics/human-genome-and-human-rights/ (accessed on 28 July 2015).

183. United Nations Educational. "Scientific and Cultural Organization International Declaration on Human Genetic Data." 2003. Available online: http://www.unesco.org/new/en/social-andhuman-sciences/themes/bioethics/human-genetic-data/ (accessed on 28 July 2015).

184. United Nations Educational. "Scientific and Cultural Organization the Universal Declaration on Bioethics and Human Rights.” 2005. Available online: http://www.unesco.org/new/en/socialand-human-sciences/themes/bioethics/bioethics-and-human-rights/ (accessed on 28 July 2015).

185. Deryck Beyleveld, and Roger Brownsword. "Human dignity, human rights, and human genetics." The Modern Law Review 61 (1998): 661-80.

186. George Kateb. Human Dignity. Cambridge: Belknap Press, 2011.

187. Andrew Brennan, and Yeuk-Sze Lo. "Two Conceptions of Dignity: Honour and Selfdetermination." In Perspectives on Human Dignity. Edited by Jeff Malpas and Norelle Lickiss. New York: Springer, 2010, pp. 43-58. 
188. Martha Nussbaum. "Human Dignity and Political Entitlements." In Human Dignity and Bioethics: Essays Commissioned by the President's Council on Bioethics. Washington: The President's Council on Bioethics, 2008, p. 357.

189. Charles Foster. Human Dignity in Bioethics and Law. Oxford: Hart, 2011.

190. Deryck Beyleveld, and Roger Brownsword. Human Dignity in Bioethics and Biolaw. Oxford: Oxford University Press, 2001.

191. Debra Mathews, and Leila Jamal. "Revisiting respect for persons in genomic research." Genes 5 (2014): 1-12.

192. Ruth Macklin. "Dignity is a useless concept: It means no more than respect for persons or their autonomy." British Medical Journal 327 (2003): 1419-20.

193. Richard Titmuss. The Gift Relationship, From Human Blood to Social Policy. London: Allen \& Unwin, 1971.

194. Lawrence Burns. "Gunther von Hagens' Body Worlds: Selling beautiful education." The American Journal of Bioethics 7 (2007): 12-23.

195. Y. Michael Barilan. "Bodyworlds and the ethics of using human remains: A preliminary discussion." Bioethics 20 (2006): 233-47.

196. Loane Skene. "Proprietary Interests in Human Bodily Material: Yearworth, Recent Australian Cases on Stored Semen and Their Implications." Medical Law Review 20 (2012): 227-45.

197. Jasper Bovenberg. "Inalienably yours? The new case for an inalienable property right in human biological material: Empowerment of sample donors or a recipe for a tragic anti-commons." SCRIPT-ed 1 (2004): 545-85.

198. Nancy Scheper-Hughes. “Alistair Cooke's bones.” Anthropology Today 22 (2006): 10-15.

199. M. D. Vedig, and D. A. Vedig. "Current privacy law governing the Australian health sector: Implications for research and 'audit'." Critical Care and Resuscitation 4 (2002): 231-37.

200. Immanuel Kant. The Metaphysics of Morals (Die Metaphysik der Sitten). Cambridge: Cambridge University Press, 1996, p. 186.

201. John Rawls. A Theory of Justice. Cambridge: Harvard University Press, 1971.

202. Laura Donnelly. "NHS hospital records used by private marketing firms." The Telegraph, 3 March 2014. Available online: http://www.telegraph.co.uk/news/nhs/10674639/NHS-hospitalrecords-used-by-private-marketing-firms.html (accessed on 28 July 2015).

203. Hansard, House of Commons Health Committee Hearing (25 February 2014).

204. Office of the UK Information Commissioner. "Information Commissioner warns that 'line in the sand' shows people recognise the value of their data." 2014. Available online: https:/ico.org.uk/ about-the-ico/news-and-events/news-and-blogs/2014/02/information-commissioner-warns-that-linein-the-sand-shows-people-recognise-the-value-of-their-data/ (accessed on 28 July 2015).

205. Jules J. Berman. "Confidentiality issues for medical data miners." Artificial Intelligence in Medicine 26 (2002): 25-36.

206. Yaniv Erlich, James B. Williams, David Glazer, Kenneth Yocum, Nita Farahany, Maynard Olson, Arvind Narayanan, Lincoln D. Stein, Jan A. Witkowski, and Robert C. Kain. "Redefining genomic privacy: Trust and empowerment." PLoS Biology 12 (2014): e1001983. 
207. Ludovic Barman, El Graini, Jean Louis Raisaro, Erman Ayday, and Jean-Pierre Hubaux. "Privacy Threats and Practical Solutions for Genetic Risk Tests." Paper presented at 2nd International Workshop on Genome Privacy and Security (GenoPri” 15), San Jose, CA, USA, 21 May 2015.

208. Khaled El Emam, Sam Rodgers, and Bradley Malin. "Anonymising and sharing individual patient data." British Medical Journal 350 (2015): h1139.

209. Jon Hoeksma. "The NHS's care.data scheme: What are the risks to privacy?" British Medical Journal 348 (2014): g1547.

210. UK Information Governance Review. "Information: To Share or Not To Share? Independent review of how information about patients is shared across the health and care system." 2013. Available online: https://www.gov.uk/government/publications/the-information-governance-review (accessed on 28 July 2015).

211. Pam Carter, Graeme Laurie, and Mary Dixon-Woods. "The social licence for research: Why care.data ran into trouble." Journal of Medical Ethics 41 (2015): 404-9.

212. Randeep Ramesh. "NHS disregards patient requests to opt out of sharing medical records." The Guardian, 22 January 2015. Available online: http://www.theguardian.com/society/2015/jan/22/ nhs-disregards-patients-requests-sharing-medical-records (accessed on 28 July 2015).

213. Brett Frischmann, Michael Madison, and Katherine Strandburg, eds. Governing Knowledge Commons. Oxford: Oxford University Press, 2014.

214. Melissa Gymrek, Amy McGuire, David Golan, Eran Halperin, and Yanev Erlich. "Identifying personal genomes by surname inference." Science 339 (2013): 321-24.

215. Aaron Doyle, Randy Lippert, and David Lyon, eds. Eyes Everywhere: The Global Growth of Camera Surveillance. London: Routledge, 2011.

216. David Lyon. Surveillance as Social Sorting: Privacy, Risk and Digital Discrimination. London: Routledge, 2003.

217. Sean Hier. Panoptic Dreams: Streetscape Video Surveillance in Canada. Vancouver: UBC Press, 2010.

218. Tim Newburn, and Stephanie Hayman. Policing, Surveillance and Social Control: CCTV and Police Monitoring of Suspects. Cullompton: Willan, 2002.

219. Beatrice von Silva-Tarouca Larsen. Setting the Watch: Privacy and the Ethics of CCTV Surveillance. Oxford: Hart, 2011.

220. Hilary Delany, and Eoin Carolan. The Right to Privacy. Dublin: Thomson Round Hall, 2008.

221. Entick v Carrington (1765), 19 St Tr 1029; (1795) 95 ER 807.

222. Michael Warby, Nicole Moreham, and Ian Christie. Tugendhat \& Christie: The Law of Privacy \& the Media. Oxford: Oxford University Press, 2011.

223. Megan Richardson, Michael Bryan, Martin Vranken, and Katy Barnett. Breach of Confidence: Social Origins and Modern Developments. Cheltenham: Edward Elgar, 2012.

224. Wolfgang Sofsky. Privacy: A Manifesto. Princeton: Princeton University Press, 2009.

225. James Rule, and Graham Greenleaf, eds. Global Privacy Protection: The First Generation. Cheltenham: Edward Elgar, 2010

226. Colin Bennett, and Charles Raab. The Governance of Privacy: Policy Instruments in Global Perspective. Cambridge: The MIT Press, 2006. 
227. Robert Gellman. "Can Privacy Be Regulated Effectively on a National Level-Thoughts on the Possible Need for International Privacy Rules." Villanova Law Review 41 (1996): 129-72.

228. Raymond Wacks. Personal Information: Privacy and the Law. Oxford: Oxford University Press, 1993.

229. Sheri Alpert. "Protecting medical privacy: Challenges in the age of genetic information." Journal of Social Issues 59 (2003): 301-22.

230. Abraham Newman. Protectors of Privacy: Regulating Personal Data in the Global Economy. Ithaca: Cornell University Press, 2008.

231. Lee Bygrave. "Privacy and data protection in an international perspective." Scandinavian Studies in Law 56 (2010): 165-200.

232. Christopher Kuner. Transborder Data Flows and Data Privacy Law. Oxford: Oxford University Press, 2012.

233. Ann Cavoukian. "Evolving FIPPs: Proactive Approaches to Privacy, Not Privacy Paternalism." In Reforming European Data Protection Law. Dordrecht: Springer Netherlands, 2015, pp. 293-309.

234. Fred Cate, Peter Cullen, and Viktor Mayer-Schönberger. Data Protection Principles for the 21st Century: Revising the 1980 OECD Guidelines. Oxford: Oxford Internet Institute, 2014.

235. Shawn Harmon. "The significance of UNESCO's universal declaration on the human genome and human rights." SCRIPT-ed 2 (2005): 18-38.

236. Shawn Harmon. "Ethical rhetoric: Genomics and the moral content of UNESCO's 'universal' declarations." Journal of Medical Ethics 34 (2008): e24.

237. David Winickoff, and Larissa B. Neumann. "Towards a social contract for genomics: Property and the public in the 'biotrust' model." Life Sciences Society and Policy 1 (2005): 8-21.

238. Jessica Litman. "Information Privacy/Information Property." Stanford Law Review 152 (2000): 1283-313.

239. James Evans, and Michael Watson. "Genetic Testing and FDA Overregulation Threatens the Emergence of Genomic Medicine.” JAMA 313 (2015): 669-70.

240. Michael Dodson, and Robert Williamson. "Indigenous peoples and the morality of the Human Genome Diversity Project." Journal of Medical Ethics 25 (1999): 204-8.

241. Gísli Pálsson. "Decode Me!” Current Anthropology 53 (2012): S185-95.

242. Misha Angrist. Here is a Human Being: At the Dawn of Personal Genomics. New York: HarperCollins, 2010.

(C) 2015 by the authors; licensee MDPI, Basel, Switzerland. This article is an open access article distributed under the terms and conditions of the Creative Commons Attribution license (http://creativecommons.org/licenses/by/4.0/). 